\title{
Comparison of Vero-cytotoxin-encoding Phages from Escherichia coli of Human and Bovine Origin
}

\author{
By P. J. G. M. RIETRA, ${ }^{1} \dagger$ G. A. WILlShAW,${ }^{1 *}$ H. R. SMITH, ${ }^{1}$ \\ A. M. FIELD, ${ }^{2}$ S. M. SCOTLAND ${ }^{1}$ AND B. ROWE \\ ${ }^{1}$ Division of Enteric Pathogens and ${ }^{2}$ Virus Reference Laboratory, Central Public Health \\ Laboratory, Colindale Avenue, London, UK
}

(Received 5 December 1988; revised 21 March 1989; accepted 17 April 1989)

\begin{abstract}
Phages encoding production of Vero cytotoxins VT1 or VT2 were isolated from strains of Escherichia coli of human and bovine origin. Two human strains of serotype O157:H7 produced both VT1 and VT2 and each carried two separate phages encoding either VT1 or VT2. The phages were morphologically similar to each other and to a VT2 phage previously isolated from a strain of serotype $0157: \mathrm{H}^{-}$; all had regular hexagonal heads and short tails. The phages had similar genome sizes and DNA hybridization and restriction enzyme digestion showed that the DNAs were very closely related. This contrasts with another report that one of the strains tested (933) released two clearly distinguishable phages separately encoding VT1 and VT2. The O157 phages differed from a VT1 phage isolated from a bovine $E$. coli strain belonging to serotype $\mathrm{O} 26: \mathrm{H} 11$ and from the reference VT1 phage isolated previously from a human strain, H19, of serotype $\mathrm{O} 26: \mathrm{H} 11$. The two $\mathrm{O} 26$ phages were morphologically similar with elongated heads and long tails. They had similar genome sizes and DNA hybridization indicated a high level of homology between them. Hybridization of an O157 phage DNA probe to DNA of the O26 phages, and vice versa, showed there was some cross-hybridization between the two types of phage. A phage from a bovine strain of serotype $\mathrm{O} 29: \mathrm{H} 34$ had a regular hexagonal head and short tail resembling those of the 0157 phages. The DNA was distinguishable from that of all the other phages tested in restriction digest patterns but hybridized significantly to that of an 0157 phage. Hybridization of the phage genomes with VT1 and VT2 gene probes showed that sequences encoding these toxins were highly conserved in the different phages from strains belonging to the three serogroups.
\end{abstract}

\section{INTRODUCTION}

Vero cytotoxin (VT) was first reported as a heat-labile cytotoxin that was produced by some strains of Escherichia coli and was active on Vero cells (Konowalchuk et al., 1977). Subsequently, it was reported that VT could be neutralized by an antiserum prepared against Shigella dysenteriae type 1 toxin and that these toxins were very similar (O'Brien et al., 1983). Scotland et al. $(1985,1987)$, however, showed that VT produced by the majority of strains of serotype O157:H7 or O157: $\mathrm{H}^{-}$could not be neutralized by anti-Shiga toxin and that a second Vero cytotoxin that did not cross-react immunologically with Shiga toxin was produced by these strains. Several $\mathrm{O} 157$ strains produced both this second toxin and the VT neutralizable by antiShiga toxin. Immunological heterogeneity of VT had been noted earlier in other Vero cytotoxigenic serogroups of $E$. coli (Konowalchuk et al., 1977; Smith et al., 1983). Scotland et al. (1985) proposed the name VT1 for the toxin that could be neutralized by anti-Shiga toxin and VT2 for the second toxin. The terms Shiga-like toxin I and II (SLTI and SLTII) are also used to

\footnotetext{
† Present address: Bacteriology Laboratory, Onze Lieve Vrouwe Gasthuis, le Oosterparkstraat 179, 1091 HA Amsterdam, The Netherlands.
} 
describe the toxins VT1 and VT2 (Strockbine et al., 1986). Specific DNA probes for VT1 and VT2 that do not cross-hybridize with each other have been developed from cloned genes (Willshaw et al., 1985, 1987).

VT production in several $E$. coli strains of human origin is due to the presence of lysogenic phages. VT-encoding phages were first isolated from $E$. coli $\mathrm{H} 19$, serotype O26:H11 (Scotland et al., 1983; Smith et al., 1983). Smith et al. (1983) also isolated phages encoding VT from a second O26 strain and from two O128 strains. Later, VT phages were detected in strains of serotype $\mathrm{O} 157: \mathrm{H} 7$ or $\mathrm{O} 157: \mathrm{H}^{-}$isolated from patients with haemorrhagic colitis or haemolytic uraemic syndrome (O'Brien et al., 1984; Smith et al., 1984). VT1-encoding phages from the serotype O26: H11 strain H19 (phage H19J) and from strain 933 of serotype O157:H7 (phage 933J) were reported by O'Brien et al. (1984) to be virtually identical in their morphology, pattern of fragments generated upon restriction enzyme digestion of phage DNA and phage polypeptides. Willshaw et al. $(1985,1987)$ isolated a VT1 phage, $\phi \mathrm{H} 19(\mathrm{VT} 1)$, from strain $\mathrm{H} 19$ that was probably identical to phage $\mathrm{H} 19 \mathrm{~J}$. It clearly differed in morphology, genome size and restriction enzyme digest pattern from a VT1-encoding phage isolated from a strain of O157:H7, E30480. This 0157-derived VT1 phage was identical or very similar in these respects to a VT2 phage from a strain of serotype $0157: \mathrm{H}^{-}, \mathrm{E} 32511$. To clarify the apparent discrepancies in the results described above, one objective of this study was to isolate separate phages encoding VT1 or VT2 from the same strain of serotype $0157: \mathrm{H} 7$ in order to compare their properties.

VT-producing $E$. coli (VTEC) have also been isolated from calves with diarrhoea and from healthy animals (Mohammad et al., 1985; Sherwood et al., 1985) and from pigs with postweaning diarrhoea or oedema disease (Smith et al., 1983). Bovine strains which belonged to a large number of O serogroups produced VT1 or VT2 but not both toxins (Marques et al., 1986; Smith et al., 1988). VTEC from pigs belonged to a limited number of serogroups; the strains hybridized with the VT2 probe and produced a toxin that was neutralized by antiserum to VT2 (Marques et al., 1987; Smith et al., 1988). In contrast with human VTEC, there have been no reports of phage-encoded VT production in strains from animals. In studies by Smith et al. (1983) and Marques et al. (1987) no toxin-converting phages were recovered from bovine or porcine VTEC. The group of VTEC from diseased animals recently characterized by Smith $e t$ al. (1988) for VT production and the presence of genes for VT1 and VT2 have now been screened for the carriage of VT phages. In this paper we report the isolation of VT-toxin-converting phages from two bovine strains and their comparison with VT phages obtained from strains of human origin. A preliminary report of this work was presented at an International Symposium and Workshop on Vero-cytotoxin-producing Escherichia coli, held in Toronto, July 1987 (Rietra et al., 1989).

\section{METHODS}

Bacterial strains. Table 1 lists the properties of four wild-type VTEC strains of human origin and two strains from bovine sources from which VT phages were isolated. Two O157:H7 strains produced both VT1 and VT2. The 34 animal VTEC screened for VT phages were those listed by Smith et al. (1988). Colonies of the strains from which VT phages were derived were checked by DNA hybridization for the presence of the appropriate VT genes. The $E$. coli K12 strain PAP1192 $\mu$ (Pugsley, 1985) was used as a phage indicator strain; it was resistant to the action of colicins produced by the wild-type strains examined. Strain PAP1192 $\mu$ was also used for preparing stable lysogens; it did not carry phage $\lambda$. Consistent with previous studies (Willshaw et al., 1985, 1987), the VT phages were identified by the number of the strain from which they were released and the type of VT that they encoded, e.g. $\phi 30480(V T 2)$.

Tests for VT production. Tests for VT production by wild-type strains and lysogenic derivatives of $E$. coli strain PAP1 $192 \mu$ and neutralization of the toxic activity by antiserum to VT1 or VT2 were done as described previously (Scotland et al., 1980, 1988). Supernatants of overnight cultures in trypticase soy broth were used as a source of toxin. Tests were done with 5-fold dilutions of culture supernatants and the titre was the highest dilution giving an effect on Vero cells.

Isolation of phages. An exponential-phase culture of a wild-type strain in L-broth ( $0.2 \mathrm{ml})$ was sterilized through a $0.45 \mu \mathrm{m}$ Millipore filter and mixed with $0.2 \mathrm{ml}$ of an exponential-phase culture of the indicator strain. After $20 \mathrm{~min}$ at $37^{\circ} \mathrm{C}$ this was mixed with $0.7 \% \mathrm{~L}$-agar and poured on a $\mathrm{L}$-agar bottom layer; the plates were incubated overnight at $37^{\circ} \mathrm{C}$. If no plaques were obtained and also when neutralization experiments had indicated that a 


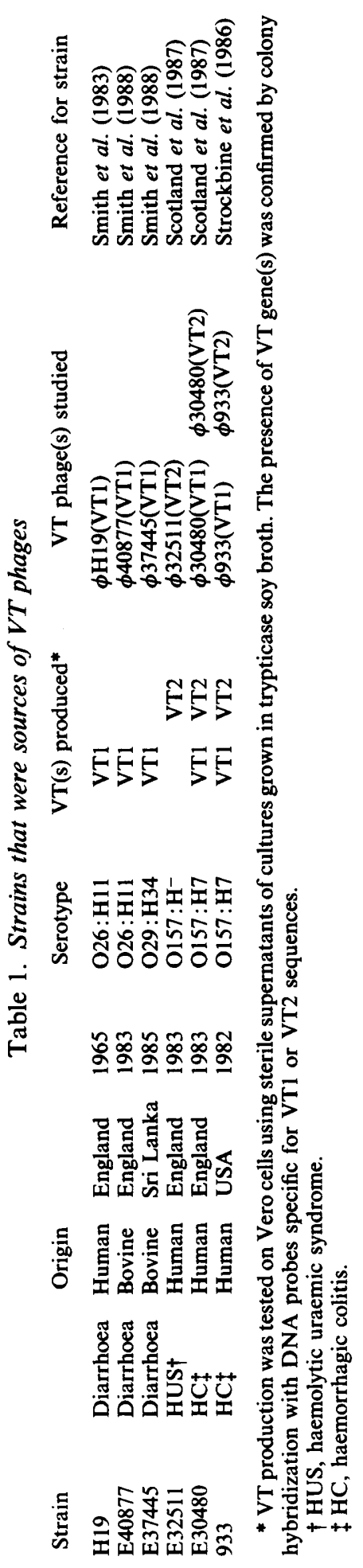


strain produced two types of toxin, UV induction was used according to the protocol of O'Brien et al. (1984). Phage particles contained within the plaques were transferred to a nylon membrane (Hybond-N; Amersham) placed on the agar surface for $1 \mathrm{~min}$. To release phage DNA and bind it to the membrane, the membrane was successively treated with $1.5 \mathrm{M}-\mathrm{NaCl}, 0.5 \mathrm{M}-\mathrm{NaOH}$ for $7 \mathrm{~min}$ and $1.5 \mathrm{M}-\mathrm{NaCl}, 0.5 \mathrm{M}-\mathrm{Tris} / \mathrm{HCl}, \mathrm{pH} 7.4$, twice for $3 \mathrm{~min}$. Membranes were washed with $2 \times \operatorname{SSC}(1 \times \operatorname{SSC}$ is $0.15 \mathrm{M}-\mathrm{NaCl}, 0.015 \mathrm{M}$-trisodium citrate, $\mathrm{pH} 7.0)$, air-dried and put on a UV transilluminator for $4 \mathrm{~min}$ to bind the DNA covalently. Membranes were successively hybridized with VT1 and VT2 probes as described below. Removal of the preceding probe from the filters was done as indicated by the manufacturer (Amersham). Hybridization signals detected on the filters were aligned with plaques on the master plates. Single plaques hybridizing with one of the probes were identified and cut from the agar with a Pasteur pipette and subjected to repeated single plaque purification.

Propagation and electron microscopy of VT phages. VT phages were propagated on E. coli PAP1 $192 \mu$ grown in L-broth containing $10 \mathrm{mM}-\mathrm{MgSO}_{4}$ (Scotland et al., 1983; Smith et al., 1984). Large scale preparation of VT phages was according to Maniatis et al. (1982). Cultures in L-broth were infected with VT phage and grown until the bacteria lysed. It was necessary to try different proportions of phage to indicator cells in order to obtain lysis of the indicator strain. After removal of cellular debris pelleted phage was treated with DNAase and RNAase and concentrated by polyethylene glycol precipitation. Phage preparations were purified by centrifugation in caesium chloride step gradients. Phage DNA was extracted with phenol and dialysed against TE buffer $(10 \mathrm{mM}$-Tris/ $\mathrm{HCl}$, $1 \mathrm{mM}$-EDTA, pH 8.0). Phage preparations for electron microscopy were prepared by the protocol of Maniatis $e t$ al. (1982) up to the polyethylene glycol precipitation. The preparation was dialysed against TE buffer and treated for electron microscopy as described previously (Willshaw et al., 1987). Measurements were made on complete and stain-penetrated ('full' and 'empty') particles. The true magnifications of the microscopes were calibrated with catalase crystals.

DNA techniques and hybridization. Treatment of VT phage DNA with restriction endonucleases, agarose gel electrophoresis and transfer of DNA fragments to nylon membranes were as described previously (Willshaw $e t$ al., 1985). Bacteria were prepared for colony hybridization by the method of Maniatis et al. (1982). DNA fragments excised from agarose gels were used as probes for the detection of VT genes; they were labelled with deoxyadenosine $5^{\prime}-\alpha-\left[{ }^{35} S\right]$ thiotriphosphate by the random primer method (Feinberg \& Vogelstein, 1983). The probe for VT1 was a $0.75 \mathrm{~kb}$ Hincll fragment derived from $\phi \mathrm{H} 19$ (VT1). It was purified from the recombinant plasmid NTP705 (Willshaw et al., 1985). The VT2 probe was a $0.85 \mathrm{~kb}$ AvaI-Pst fragment of the recombinant plasmid NTP707 derived from $\phi 32511$ (VT2) (Willshaw et al., 1987). These probes do not cross-hybridize with each other under the conditions used. Nucleotide sequencing of the VT1 and VT2 genes (Jackson et al., 1987) indicated that the VT1 and VT2 probes used are located internally in the gene sequences and contain no flanking phage DNA. For demonstrating relatedness between the phages from different serotypes, BamHI-digested DNA of $\phi 933(\mathrm{VT1})$ and $\phi \mathrm{H} 19$ (VT1) were labelled as described above. They were used as probes in hybridization with restriction-endonuclease-cleaved DNA of all the phages that had been blotted to nylon membranes.

DNA hybridization was done at $42^{\circ} \mathrm{C}$ in a mixture containing $50 \%(\mathrm{v} / \mathrm{v})$ formamide, $5 \times$ SSPE $(1 \times$ SSPE is $\left.0.18 \mathrm{M}-\mathrm{NaCl}, 10 \mathrm{mM}-\mathrm{NaH}_{2} \mathrm{PO}_{4}, 1 \mathrm{mM}-\mathrm{EDTA}, \mathrm{pH} 7 \cdot 4\right), 0 \cdot 1 \%$ each of Ficoll $\left(M_{\mathrm{r}} 400000\right)$, polyvinylpyrrolidone, bovine serum albumin and SDS, and $0.01 \mathrm{M}$-dithiothreitol and $100 \mu \mathrm{g}$ denatured salmon sperm DNA ml-1. Washing under high stringency conditions and autoradiography were as described by Willshaw et al. (1985). When membranes were hybridized sequentially with more than one probe, the preceding probe was removed under the conditions described by the membrane manufacturer (Amersham).

Preparation of lysogens and tests of phage immunity. Lysogens in strain PAP1 $192 \mu$ were prepared by spotting high titre (about $10^{11}$ p.f.u. $\mathrm{ml}^{-1}$ ) phage preparations on lawns of these strains and subculturing resistant growth from areas of confluent lysis. Up to 50 colonies of possible lysogens were tested by repeatedly subculturing and testing for immunity to the homologous phage. Two or three strains that appeared to be stable lysogens were tested for VT production using Vero cells. In addition, lysogens were plated to obtain separate colonies which were tested by hybridization.

Stock phage preparations were diluted to about $10^{8}$ to $10^{9}$ p.f.u. $\mathrm{ml}^{-1}$ and these gave confluent lysis with strain PAP1 $192 \mu$ as indicator. These phage preparations were spotted on lawns of the stable E. coli K12 lysogens to test for immunity. For the immunity tests all the lysogens were strain PAP1192 $\mu$.

\section{RESULTS}

\section{Isolation of VT phages}

From the six E. coli strains shown in Table 1, a total of eight VT-encoding phages have been isolated. $\phi \mathrm{H} 19$ (VT1) and $\phi 32511(\mathrm{VT} 2)$, respectively, are standard VT1 and VT2 phages (Willshaw et al., 1987). Phages $\phi 30480(V T 1)$ and $\phi 933$ (VT2) were previously recovered from strains E30480 and 933 respectively (Willshaw et al., 1987) and are included for comparison with the newly isolated phages described below. 
Table 2. Properties of VT phages

$n$, Number of particles measured. Values for $\phi \mathrm{H} 19(\mathrm{VT} 1)$ and $\phi 30480(\mathrm{VT} 1)$ have been reported previously (Willshaw et al., 1987).

\begin{tabular}{|c|c|c|c|c|c|c|c|}
\hline \multirow[b]{3}{*}{ Phage } & \multicolumn{6}{|c|}{ Size of phage particles (nm) } & \multirow{3}{*}{$\begin{array}{c}\text { Molecular size } \\
\text { of phage DNA } \\
(\mathrm{kb})^{*}\end{array}$} \\
\hline & \multicolumn{3}{|c|}{ Head } & \multicolumn{3}{|c|}{ Tail } & \\
\hline & $\begin{array}{l}\text { Mean } \\
\text { length }\end{array}$ & $\begin{array}{l}\text { Mean } \\
\text { width }\end{array}$ & $(n)$ & $\begin{array}{l}\text { Mean } \\
\text { length }\end{array}$ & $\begin{array}{l}\text { Mean } \\
\text { width }\end{array}$ & (n) & \\
\hline $\begin{array}{l}\phi \mathrm{H} 19(\mathrm{VT} 1) \\
\phi 40877(\mathrm{VT} 1)\end{array}$ & $\begin{array}{l}116 \\
100\end{array}$ & $\begin{array}{l}66 \\
55\end{array}$ & $\begin{array}{r}(57) \\
(4)\end{array}$ & $\begin{array}{l}177 \\
190\end{array}$ & $\begin{array}{l}12 \\
10\end{array}$ & $\begin{array}{r}(29) \\
(5)\end{array}$ & $\begin{array}{l}52 \\
53\end{array}$ \\
\hline$\phi 37445$ (VT1) & 72 & 73 & (28) & 27 & 13 & (15) & 70 \\
\hline$\phi 32511$ (VT2) & 73 & 74 & $(40)$ & 29 & 11 & (19) & 68 \\
\hline $\begin{array}{l}\phi 30480(\mathrm{VT} 1) \\
\phi 30480(\mathrm{VT} 2)\end{array}$ & $\begin{array}{l}73 \\
72\end{array}$ & $\begin{array}{l}73 \\
73\end{array}$ & $\begin{array}{l}(50) \\
(18)\end{array}$ & $\begin{array}{l}28 \\
27\end{array}$ & $\begin{array}{l}11 \\
16\end{array}$ & $\begin{array}{l}(15) \\
(13)\end{array}$ & $\begin{array}{l}62 \\
69\end{array}$ \\
\hline $\begin{array}{l}\phi 933(\mathrm{VT} 1) \\
\phi 933(\mathrm{VT} 2)\end{array}$ & $\begin{array}{l}71 \\
69\end{array}$ & $\begin{array}{l}70 \\
66\end{array}$ & $\begin{array}{l}(13) \\
(11)\end{array}$ & $\begin{array}{l}28 \\
22\end{array}$ & $\begin{array}{l}17 \\
16\end{array}$ & $\begin{array}{r}(15) \\
(6)\end{array}$ & $\begin{array}{l}66 \\
68\end{array}$ \\
\hline
\end{tabular}

* Values for $\phi$ H19(VT1), $\phi 32511$ (VT2), $\phi 30480(V T 1)$ and $\phi 933(V T 2)$ (Willshaw et al., 1987) are included for comparative purposes. Sizes are means of at least four determinations. Fragment sizes were calculated relative to the fragments of phage $\lambda$ digested with HindIII or HindIII plus EcoRI.

Hybridization of VT1 and VT2 probes to phage plaques transferred to nylon membrane detected the presence of both VT1- and VT2-encoding phage in strains E30480 and 933. The plaque-hybridization experiments were done at least twice and the values quoted are the means of two or three experiments. However, the ease with which different phages were released into the culture supernatants varied. In the absence of $U V$ induction $5 \times 10^{2}$ p.f.u. $\mathrm{ml}^{-1}$ were present in a culture supernatant of strain 933 but all the plaques hybridized with the VT2 probe only and presumably contained $\phi 933$ (VT2). After UV induction the phage titre was $5 \times 10^{4}$ p.f.u. $\mathrm{ml}^{-1}$ and $0.2 \%$ of these plaques hybridized with the VT1 probe only and the remainder with the VT2 probe only. Previously, only the spontaneous release of a VT1 phage $\phi 30480$ (VT1) had been observed from E30480 (Willshaw et al., 1987). In the present study both VT1- and VT2-encoding phages were readily released in the supernatant of a UV-induced culture of strain E30480: the proportion of plaques hybridizing with VT1 or VT2 probes was $1: 3$.

Thirty-four VTEC of animal origin belonging to $13 \mathrm{O}$ serogroups were also examined for the presence of phage. Two of the 14 strains from pigs released phage but the plaques did not hybridize with either VT probe; no phage plaques were obtained from the remaining strains. Of 20 bovine VTEC, 13 yielded no phage plaques, five yielded plaques not hybridizing to either VT probe and two strains released phages encoding VT1. A culture supernatant of E37445 (serotype $\mathrm{O} 29: \mathrm{H} 34$ ) contained 20 p.f.u. $\mathrm{ml}^{-1}$. E40877 (serotype $\mathrm{O} 26: \mathrm{H} 11$ ) did not release phage particles spontaneously but 5 p.f.u. $\mathrm{ml}^{-1}$ were present in a supernatant after $\mathrm{UV}$ induction.

\section{Morphology of VT phages}

Morphologically, the phages fell into two groups illustrated in Fig. 1. Those from serogroup O26 had elongated hexagonal heads and long tails, whereas phages from strains of serogroups O157 and O29 had regular hexagonal heads and short tails (Fig. 1, Table 2). The VT1 and VT2 phages from the same $\mathrm{O} 157$ strain were morphologically similar in both instances.

\section{Properties of lysogens and testing for phage immunity}

Lysogenic derivatives of strain PAP $1192 \mu$ were prepared from the eight phages listed in Table 1. Toxin titres of wild-type strains and PAP1192 $\mu$ lysogens were determined at least twice and results of a representative experiment are shown in Table 3. Some differences were observed between the titres given by the wild-type strains and the corresponding lysogens. However, since 5-fold dilutions were tested and the differences usually represented only one dilution factor, they are not considered significant. The type of toxin was determined by 

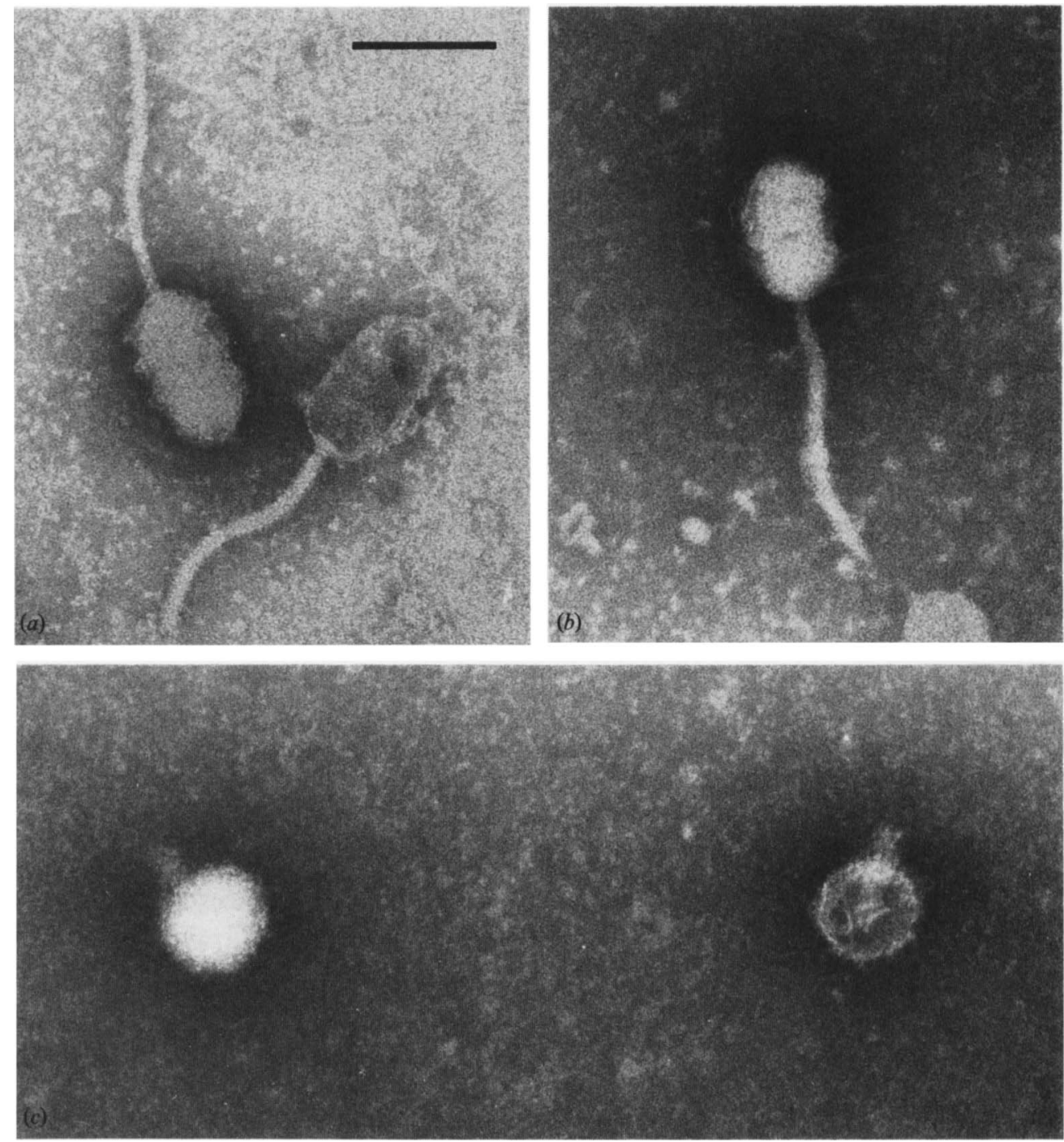

Fig. 1. Electron microscopy of VT phages. Phage suspensions were stained with $3 \%(w / v)$ phosphotungstic acid. Bar, $100 \mathrm{~nm}$. (a) Phage from strain H19, serotype O26:H11 that codes for production of VT1 [ $\phi \mathrm{H} 19(\mathrm{VT} 1)]$; (b) phage from strain E40877, serotype O26:H11 that codes for production of VT1 [ $\phi 40877(\mathrm{VT} 1)]$; $(c)$ Phage from strain 933, serotype O157:H7 that codes for production of VT1 [ $\phi 933(\mathrm{VT} 1)]$. The following phages had the same morphology as $\phi 933(\mathrm{VT} 1)$ : $\phi 933(\mathrm{VT} 2), \phi 30480(\mathrm{VT} 1), \phi 30480(\mathrm{VT} 2), \phi 32511(\mathrm{VT} 2)$ and $\phi 37445(\mathrm{VT} 1)$.

neutralization with specific antisera (Table 3). Strain PAP1 $192 \mu$ lysogenized with the purified phages produced either VT1 or VT2 but not both toxins. The type of toxin determined by neutralization was always in agreement with the hybridization results obtained with the VT1 and VT2 probes on Southern blots of phage DNA or colony hybridization with E. coli K12 lysogens and wild-type strains. There was only partial neutralization in testing E30480 and 933 with anti-VT2 and no neutralization with anti-VT1. However, complete neutralization was observed when both antisera were used together, suggesting that in these supernatants there was more VT2 than VT1. The indicator strain did not hybridize with either of the VT probes or produce VT. 
Table 3. Toxin titres and neutralization tests with wild-type strains and K12 lysogens

\begin{tabular}{|c|c|c|c|c|c|c|}
\hline \multirow{2}{*}{$\begin{array}{l}\text { Wild-type } \\
\text { E. coli strain* }\end{array}$} & \multirow{2}{*}{$\begin{array}{c}\text { PAP } 1192 \mu \\
\text { lysogen carrying } \\
\text { phage }\end{array}$} & \multirow[b]{2}{*}{ VT gene* } & \multirow[b]{2}{*}{ VT titre $†$} & \multicolumn{3}{|c|}{ Neutralized by: } \\
\hline & & & & anti-VT1 & anti-VT2 & anti-VT1 + anti-VT2 \\
\hline H19 & $\phi \mathrm{H} 19(\mathrm{VT} 1)$ & $\begin{array}{l}\text { VT1 } \\
\text { VT1 }\end{array}$ & $\begin{array}{l}6250 \\
6250\end{array}$ & $\begin{array}{l}\text { Yes } \\
\text { Yes }\end{array}$ & $\begin{array}{l}\text { No } \\
\text { No }\end{array}$ & $\begin{array}{l}\text { Yes } \\
\text { Yes }\end{array}$ \\
\hline E40877 & $\phi 40877(\mathrm{VT} 1)$ & $\begin{array}{l}\text { VT1 } \\
\text { VT1 }\end{array}$ & $\begin{array}{r}31250 \\
6250\end{array}$ & $\begin{array}{l}\text { Yes } \\
\text { Yes }\end{array}$ & $\begin{array}{l}\text { No } \\
\text { No }\end{array}$ & $\begin{array}{l}\text { Yes } \\
\text { Yes }\end{array}$ \\
\hline E37445 & $\phi 37445(\mathrm{VT} 1)$ & $\begin{array}{l}\text { VT1 } \\
\text { VT1 }\end{array}$ & $\begin{array}{r}250 \\
1250\end{array}$ & $\begin{array}{l}\text { Yes } \\
\text { Yes }\end{array}$ & $\begin{array}{l}\text { No } \\
\text { No }\end{array}$ & $\begin{array}{l}\text { Yes } \\
\text { Yes }\end{array}$ \\
\hline E32511 & $\phi 32511(\mathrm{VT} 2)$ & $\begin{array}{l}\text { VT2 } \\
\text { VT2 }\end{array}$ & $\begin{array}{r}31250 \\
781250\end{array}$ & $\begin{array}{l}\text { No } \\
\text { No }\end{array}$ & $\begin{array}{l}\text { Yes } \\
\text { Yes }\end{array}$ & $\begin{array}{l}\text { Yes } \\
\text { Yes }\end{array}$ \\
\hline E30480 & $\begin{array}{l}\phi 30480(\mathrm{VT} 1) \\
\phi 30480(\mathrm{VT} 2)\end{array}$ & $\begin{array}{l}\text { VT1 + VT2 } \\
\text { VT1 } \\
\text { VT2 }\end{array}$ & $\begin{array}{r}1250 \\
6250 \\
250\end{array}$ & $\begin{array}{l}\text { No } \\
\text { Yes } \\
\text { No }\end{array}$ & $\begin{array}{l}\text { Partial } \\
\text { No } \\
\text { Yes }\end{array}$ & $\begin{array}{l}\text { Yes } \\
\text { Yes } \\
\text { Yes }\end{array}$ \\
\hline 933 & $\begin{array}{c}- \\
\phi 933(\mathrm{VT} 1) \\
\phi 933(\mathrm{VT} 2)\end{array}$ & $\begin{array}{l}\text { VT1 + VT2 } \\
\text { VT1 } \\
\text { VT2 }\end{array}$ & $\begin{array}{l}6250 \\
1250 \\
6250\end{array}$ & $\begin{array}{l}\text { No } \\
\text { Yes } \\
\text { No }\end{array}$ & $\begin{array}{l}\text { Partial } \\
\text { No } \\
\text { Yes }\end{array}$ & $\begin{array}{l}\text { Yes } \\
\text { Yes } \\
\text { Yes }\end{array}$ \\
\hline
\end{tabular}

* Detected by hybridization with specific gene probes.

$\dagger$ Tests were done with 5-fold dilutions of culture supernatants. Titre was highest dilution giving an effect on Vero cells.

Table 4. Immunity of E. coli K12 lysogens to VT phages isolated from wild-type strains + , Confluent lysis; -, no lysis; +/-, reduction in phage titre compared to control; $\square$, effect on homologous lysogen.

\begin{tabular}{|c|c|c|c|c|c|c|c|c|c|}
\hline \multirow{2}{*}{$\begin{array}{l}\text { PAPl192 } \mu \\
\text { lysogen } \\
\text { carrying } \\
\text { phage }\end{array}$} & \multirow[b]{2}{*}{ Phage } & \multicolumn{5}{|c|}{ From 0157} & \multicolumn{2}{|c|}{ From $\mathrm{O} 26$} & \multirow{2}{*}{$\overbrace{\begin{array}{c}\phi 37445 \\
\text { (VT1) }\end{array}}^{\text {From O29 }}$} \\
\hline & & $\begin{array}{r}\ldots 32511 \\
\text { (VT2) }\end{array}$ & $\begin{array}{l}\phi 933 \\
\text { (VT1) }\end{array}$ & $\begin{array}{l}\phi 933 \\
\text { (VT2) }\end{array}$ & $\begin{array}{c}\phi 30480 \\
\text { (VT1) }\end{array}$ & $\begin{array}{l}\phi 30480 \\
\text { (VT2) }\end{array}$ & $\begin{array}{l}\phi \mathrm{H} 19 \\
\text { (VT1) }\end{array}$ & $\begin{array}{r}\phi 40877 \\
\text { (VT1) }\end{array}$ & \\
\hline$\phi 32511$ (VT2) & & $\boxminus$ & - & $+1-$ & + & + & + & - & + \\
\hline$\phi 933(\mathrm{VT} 1)$ & & + & $\square$ & - & + & + & + & - & + \\
\hline$\phi 933(\mathrm{VT} 2)$ & & - & - & $\square$ & + & + & - & - & + \\
\hline$\phi 30480(\mathrm{VT} 1)$ & & + & - & - & $\boxminus$ & - & + & - & + \\
\hline$\phi 30480(\mathrm{VT} 2)$ & & + & - & - & - & $\square$ & + & - & + \\
\hline$\phi \mathrm{H} 19(\mathrm{VT} 1)$ & & + & + & + & + & + & $\square$ & + & + \\
\hline$\phi 40877(\mathrm{VT} 1)$ & & + & - & - & + & + & + & $\square$ & + \\
\hline$\phi 37445$ (VT1) & & + & + & + & + & + & + & + & $\theta$ \\
\hline None & & + & + & + & + & + & + & + & + \\
\hline
\end{tabular}

Table 4 shows to what extent lysogens are immune to the action of the different VT phages. As expected, the lysogen was always immune to its own phage. There were several different immunity patterns and some phages isolated from strains of the same serogroup also gave significant differences. However, the VT1- and VT2-encoding phages from the same strain had identical (E30480) or very similar (933) immunity reactions. The pattern of $\phi H 19$ (VT1) differed clearly from that of $\phi 933(\mathrm{VT} 1)$. The reactions of $\phi 37445$ (VT1) were quite distinct from the other phages.

\section{Comparison of phage DNA}

The molecular size of the phage DNA was estimated from summation of the sizes of fragments in excess of $0.3 \mathrm{~kb}$ generated by the restriction enzyme EcoRI. The DNA of the O26 phages was significantly smaller $(52-53 \mathrm{~kb})$ than that of phages isolated from the $\mathrm{O} 157$ and $\mathrm{O} 29$ strains which ranged from $62-70 \mathrm{~kb}$. 
(i)

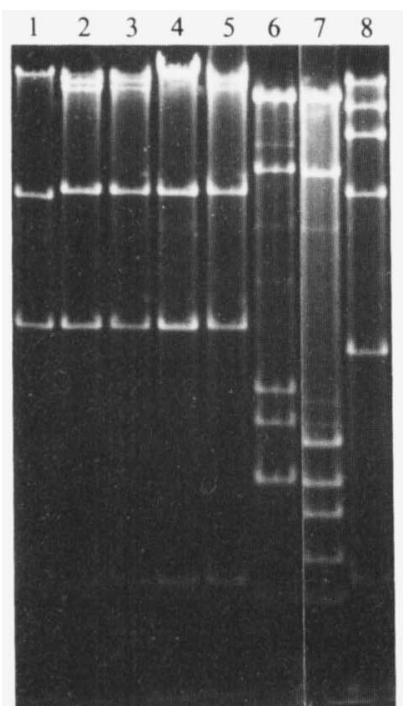

(ii)

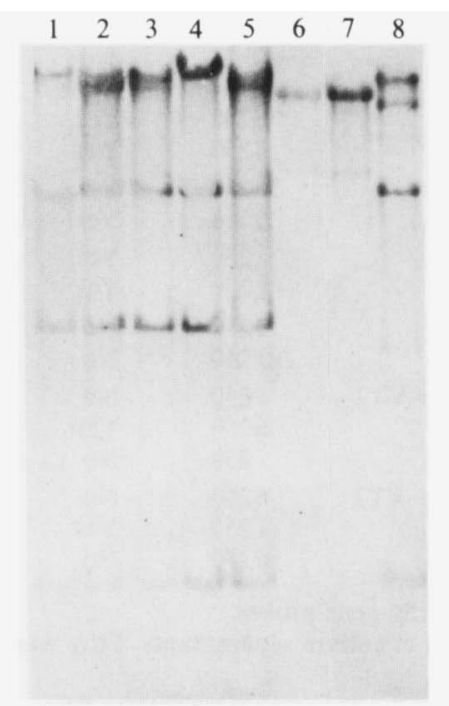

(iii)

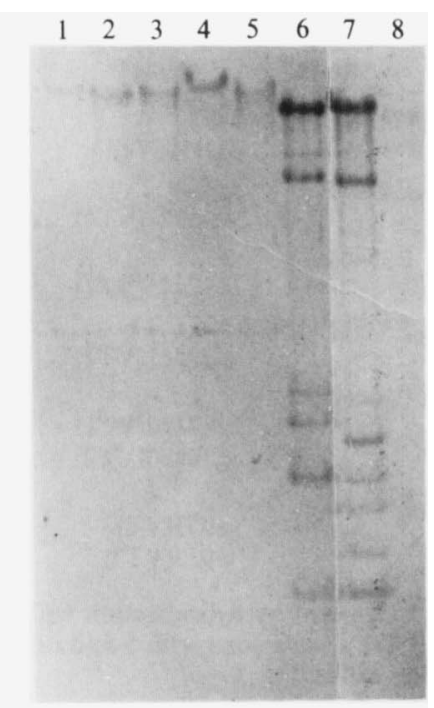

Fig. 2. Hybridization of phage DNA probes to BamHI fragments of VT phages. DNA of the VT phages listed below was digested with $B a m H I$ and the fragments separated on a $1 \%(w / v)$ agarose gel (panel i). The fragments were blotted to nylon membrane and hybridized sequentially with a ${ }^{35}$ S-labelled BamHI digest of (ii) $\phi 933$ (VT1) and (iii) $\phi$ H19(VT1). Probe labelling and hybridization were as described in Methods. The presence of hybridizing bands was detected by autoradiography. The tracks contained DNA of the following VT phages: $1, \phi 32511$ (VT2); 2, $\phi 933(\mathrm{VT} 1) ; 3, \phi 933(\mathrm{VT} 2)$; 4, $\phi 30480(\mathrm{VT} 1) ; 5, \phi 30480(\mathrm{VT} 2) ; 6, \phi \mathrm{H} 19(\mathrm{VT} 1) ; 7, \phi 40877(\mathrm{VT} 1) ; 8, \phi 37445(\mathrm{VT} 1)$.

The DNA of the phages was digested with BamHI and the separated fragments blotted from the agarose gel to nylon membrane. To demonstrate relatedness between the phages, the membrane was hybridized sequentially with probes consisting of ${ }^{35} \mathrm{~S}$-labelled $\mathrm{BamHI}$ digests of $\phi 933$ (VT1) and $\phi$ H19(VT1) DNA, respectively. Fig. 2(i) shows the BamHI digests and the autoradiograms obtained after hybridization are depicted in Fig. 2(ii) for the $\phi 933$ (VT1) probe and Fig. 2(iii) for the $\phi \mathrm{H} 19$ (VT1) probe. All five phages from the O157 strains were very similar with four $B a m H I$ fragments of $0 \cdot 4,0 \cdot 9,3 \cdot 1$ and $6 \cdot 3 \mathrm{~kb}$ plus a slowly migrating band that was not sized. All the fragments of these phages hybridized with the $\phi 933$ (VT1) probe DNA (Fig. 2ii, tracks 1-5) indicating that the phage DNAs were very similar to each other. The BamHI digests of the phages from strains of serogroup $\mathrm{O} 157$ were clearly different from those of the $\mathrm{O} 26$ phages (Fig. 2i). The $\phi 933$ (VT1) probe hybridized with a BamHI fragment of about $18 \mathrm{~kb}$ in the digests of the O26 phages $\phi \mathrm{H} 19$ (VT1) and $\phi 40877$ (VT1) (Fig. 2ii, tracks 6 and 7). The VT1 probe had been shown previously to hybridize with a BamHI fragment of this size in $\phi \mathrm{H} 19$ (VT1) or $\phi 40877$ (VT1) (not shown). The $\phi 933$ (VT1) probe hybridized with six of the seven BamHI fragments of $\phi 37445$ (VT1) (Fig. 2ii, track 8) and three of the hybridizing fragments were the same size as Bam HI fragments of the $\mathrm{O} 157$ phages.

The $\mathrm{O} 26$ phages of $\phi \mathrm{H} 19$ (VT1) and $\phi 40877(\mathrm{VT} 1)$ were distinguishable by their BamHI digests but appeared to contain four fragments of similar size (Fig. 2i). The $\phi$ H19(VT1) probe DNA hybridized to all the fragments of $\phi 40877$ (VT1) indicating that these phages were highly homologous (Fig. 2iii, tracks 6 and 7). Probing the 0157 phage DNA digests with the $\phi$ H19(VT1) DNA indicated two hybridizing bands, one of $3.1 \mathrm{~kb}$ and the other very large, irrespective of whether the target DNA contained VT1 or VT2 genes (Fig. 2 iii, tracks 1-5). This indicated that there was DNA homology between the $\mathrm{O} 157$ and $\mathrm{O} 26$ phages that did not involve the VT genes. The $\phi \mathrm{H} 19$ (VT1) probe hybridized with three fragments of $\phi 37445(\mathrm{VT} 1)$ but the signal was weak (Fig. 2iii, track 8). 
(i)

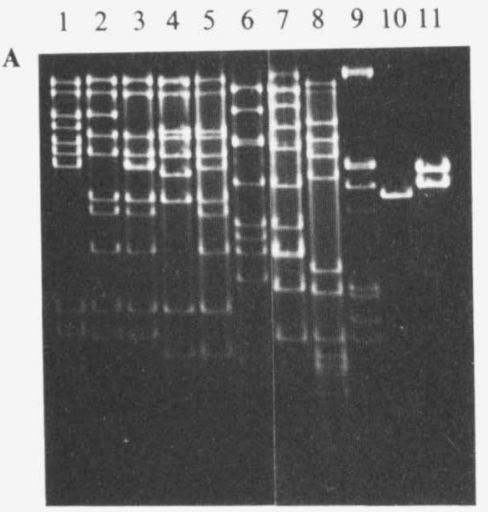

(ii)

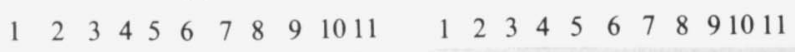

(iii) (i)

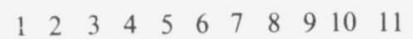

B

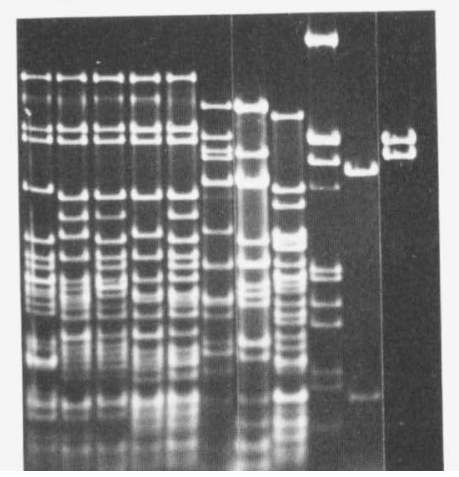

(ii)

$\begin{array}{lllllllllll}1 & 2 & 3 & 4 & 5 & 6 & 7 & 8 & 9 & 10 & 11\end{array}$

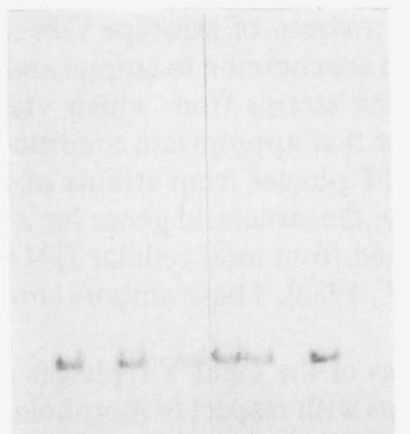

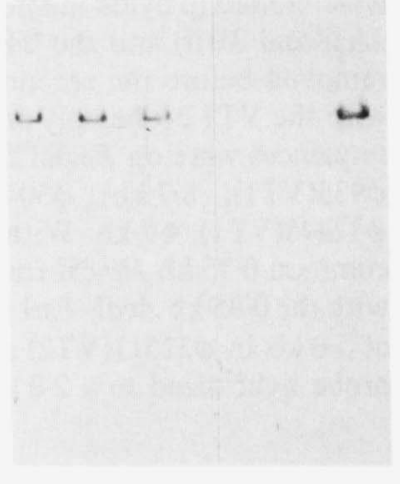

(iii)

$122 \quad 3 \quad 4 \quad 56677891011$
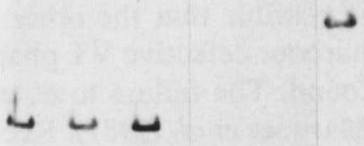

Fig. 3. Restriction enzyme digestion of phages encoding VT1 or VT2 and Southern hybridization with VT1 and VT2 probes. Block A. Panel (i) shows EcoRI fragments of phage DNA separated on a $1 \%$ (w/v) agarose gel. The material from panel (i) was blotted to nylon membrane and hybridized sequentially with (ii) the VT1 probe and (iii) the VT2 probe as described in Methods. Block B. Panel (i) shows the same DNA digested with HincII and hybridized with (ii) the VT1 probe and (iii) the VT2 probe. For A and B the DNAs present in the tracks were as follows: 1, $\phi 32511$ (VT2); $2, \phi 933$ (VT1); 3, $\phi 933$ (VT2); 4, $\phi 30480$ (VT1); 5, $\phi 30480(V T 2) ; 6, \phi H 19(V T 1) ; 7, \phi 40877(V T 1) ; 8, \phi 37445(V T 1)$. Control tracks contained: 9 , molecular size marker [ $\lambda$ phage treated with $E c o$ RI and HindIII; sizes of fragments (kb) 22.5, 5.61, 5.38, 4.49, 3.63, 2.11, 2.03, 1.69, 1.40,1.00, 0.90 and 0.61]; 10, NTP705 digested with HincII; 11, NTP707 digested with EcoRI. NTP705 and NTP707 were recombinant plasmids containing, respectively, cloned VT1 and VT2 sequences that were the sources of the VT1 and VT2 probes (see Methods). The VT1 probe hybridized to a $0.75 \mathrm{~kb}$ HincII fragment of NTP705 (track 10) whereas the VT2 probe hybridized to a $5 \mathrm{~kb}$ EcoRI fragment of NTP707 (track 11). The weakly hybridizing upper bands in A(ii), tracks 6 and 7, are probably due to detection by the probe of partially digested phage fragments. The observation cannot be due to detection of non-VT1 DNA since the probe used was internal to the VT1 sequence (Jackson et al., 1987).

Digestion of the five $\mathrm{O} 157$ phages with more-frequently cutting enzymes such as EcoRI or HincII also indicated that all were very similar irrespective of whether they encoded VT1 or VT2 (Fig. 3A, B). The fragment patterns of the VT1 and VT2 phages from the same strain differed in only one to four fragments. These digests also showed similarities between the O26 phages of animal and human origin although this was not as marked as for the 0157 phages. The phages 
from $\mathrm{O} 26$ strains were clearly different from the 0157 phages and from $\phi 37445$ (VT1). To identify fragments containing the VT genes, DNA fragments of the HincII and EcoRI digests were blotted to nylon membranes and hybridized successively with the $0.75 \mathrm{~kb}$ VT1 probe (Fig. $3 \mathrm{Aii}$ and $3 \mathrm{Bii}$ ) and the $0.85 \mathrm{~kb}$ VT2 probe (Fig. $3 \mathrm{~A}$ iii and $3 \mathrm{Biii}$ ); the preceding probe was removed before the second hybridization. Digests of VT1-encoding phage DNA hybridized with the VT1 probe only and digests of VT2 phages hybridized only with the VT2 probe. VT1 sequences were on EcoRI fragments of the following sizes in the different phages (Fig. 3Aii): $\phi 933(\mathrm{VT} 1), 8.7 \mathrm{~kb} ; \phi 30480(\mathrm{VT} 1), 4.7 \mathrm{~kb} ; \phi \mathrm{H} 19(\mathrm{VT} 1), 9.2 \mathrm{~kb} ; \phi 40877(\mathrm{VT} 1), 10.5 \mathrm{~kb}$; $\phi 37445(\mathrm{VT1}), 4.7 \mathrm{~kb}$. Within these fragments all the VT1 phages carried VT1 sequences on a common $0.75 \mathrm{~kb}$ HincII fragment identical in size to the VT1 probe (Fig. 3Bii). Hybridization with the $0.85 \mathrm{~kb}$ AvaI-PstI probe for VT2 showed that VT2 sequences were on EcoRI fragments of $5.0 \mathrm{~kb}$ in $\phi 32511(\mathrm{VT} 2)$ and $\phi 933$ (VT2) and $4.8 \mathrm{~kb}$ in $\phi 30480(\mathrm{VT} 2)$ (Fig. 3Aii). The VT2 probe hybridized to a $2.0 \mathrm{~kb}$ HincII fragment of these phage DNAs (Fig. 3Biii).

\section{DISCUSSION}

The difficulty with which VT-converting phages are recovered from some VTEC strains is attested by the low titres obtained even after UV induction. The isolation of separate phages encoding VT1 and VT2 from a single strain of serotype O157:H7 that produced both toxins was achieved by plaque hybridization with VT probes. These allowed the detection of small numbers of probe-positive plaques among a background of non-hybridizing ones. The VT1-encoding phages isolated from VTEC of bovine origin are the first to be reported in strains from a nonhuman source. One was from a strain of serotype $\mathrm{O} 26: \mathrm{H} 11$ and it has been noted that this serotype is one of the few which are common to animal and human VTEC (Smith et al., 1988). It is possible that the other bovine strains from which viable phage were not recovered could harbour defective VT phages or that appropriate conditions for release of phage have not been found. The failure to obtain VT phages from strains of porcine origin confirm the results of Marques et al. (1987). Recently, the structural genes for a variant of SLTII, active on Vero but not HeLa cells, have been cloned from total cellular DNA of an $E$. coli strain causing oedema disease in pigs (Weinstein et al., 1988). These authors concluded that the toxin sequences were chromosomally located.

Comparison of the properties of the eight VT phages studied here showed diversity in the phages from different serogroups with respect to morphology, phage immunity and composition of non-VT encoding DNA. Nevertheless, VT1 sequences were conserved on a $0.75 \mathrm{~kb}$ HincII fragment, and VT2 sequences on a $2 \mathrm{~kb}$ HinclI fragment. The phages from the serogroup 0157 strains formed a closely related group as indicated by their identical morphology, similar genome size and high level of DNA homology. VT1 and VT2 phages from the same strain showed minimal differences in DNA digests and immunity reactions that were identical (E30480 phages) or nearly so (933 phages). The O26 phages were similar to each other in morphology and the BamHI fragments of the phage from the strain of human origin hybridized with all those of the phage from the bovine strain. The phages gave distinct restriction enzyme patterns but this would not be surprising in view of the widely different isolation dates, hosts and geographical sources of the $\mathrm{O} 26$ strains. Based on the properties studied here, the phages from O26 and 0157 strains appeared to form two distinct groups, but nevertheless there was some DNA homology between them involving phage sequences and not merely VT1 genes. The VT phage from the bovine strain of serogroup $\mathrm{O} 29$ was similar in morphology and genome size to the phages from the human 0157 strains and appeared to have more DNA homology with them than with the $\mathrm{O} 26$ phages.

Our finding that the VT1 phage from strain 933 was of the regular hexagonal type and very similar to $\phi 933$ (VT2) contrasts with the results of O'Brien et al. (1984) who reported that this strain carried a VT1-encoding phage $933 \mathrm{~J}$ indistinguishable from a VT1 phage $\mathrm{H} 19 \mathrm{~J}$ in the $\mathrm{O} 26$ strain H19. Phage 933J was also described by Strockbine et al. (1986) as one of the two VT phages present in E. coli 933 . We have examined another 0157 strain of different origin to 933 and obtained VT1 and VT2 phages similar to each other and to $\phi 933$ (VT1) and $\phi 933$ (VT2). No 
evidence for the presence of phages resembling H19J or $\phi \mathrm{H} 19$ (VT1), which are probably independent isolates of the same phage, was obtained for either strain. It is possible that strain 933 could contain another VT1-encoding phage of the 'O26 type' that we have not yet isolated or that recombination of VT1 genes with a resident coliphage in strain 933 could fortuitously produce a phage resembling $933 \mathrm{~J}$. The identity of the VT1 phage of strain 933 is important because recently a non-toxin-coding $E c o$ RI fragment of phage 'H19A/933J' has been proposed as a probe to screen strains for the presence of VT-phage-associated sequences (Newland \& Neill, 1988). No fragment of this size $(6 \mathrm{~kb})$ was present in our digest of $\phi 933$ (VT1) and in $\phi \mathrm{H} 19$ (VT1) two closely migrating fragments of approximately this size were observed.

It is remarkable that in an E. coli 0157 strain producing VT1 and VT2, two phages can co-exist that are so similar in their properties except for the VT-encoding sequences. A further study of these phages and the way in which they are maintained in the strains is warranted.

P. J. G. M. Rietra was supported by a grant from the Niels Stensen Stichting, Amsterdam, The Netherlands.

\section{REFERENCES}

Feinberg, A. P. \& Vogelstein, B. (1983). A technique for radiolabelling DNA restriction endonuclease fragments to high specific activity. Analytical Biochemistry 132, 6-13.

Jackson, M. P., NeIll, R. J., O'Brien, A. D., Holmes, R. K. \& Newland, J. W. (1987). Nucleotide sequence analysis and comparison of the structural genes for Shiga-like toxin I and Shiga-like toxin II encoded by bacteriophages from Escherichia coli 933 . FEMS Microbiology Letters 44, 109-114.

Konowalchuk, J., Speirs, J. I. \& Stavric, S. (1977). Vero response to a cytotoxin of Escherichia coli. Infection and Immunity 18, 775-779.

Maniatis, T., Fritsch, E. F. \& Sambrook, J. (1982). Molecular Cloning: a Laboratory Manual. Cold Spring Harbor, NY: Cold Spring Harbor Laboratory.

Marques, L. R. M., Moore, M. A., Wells, J. G., Wachsmuth, K. \& O'Brien, A. D. (1986). Production of Shiga-like toxin by Escherichia coli. Journal of Infectious Diseases 154, 338-341.

Marques, L. R. M., Peiris, J. S. M., Cryz, S. J. \& O'BRIEN, A. D. (1987). Escherichia coli strains isolated from pigs with edema disease produce a variant of Shiga-like toxin II. FEMS Microbiology Letters 44, 33-38.

Mohammad, A., Peiris, J. S. M., Wijewanta, E. A., Mahalingham, S. \& Gunasekara, G. (1985). Role of verocytotoxigenic Escherichia coli in cattle and buffalo calf diarrhoea. FEMS Microbiology Letters 26, 281-283.

Newland, J. W. \& Neill, R. J. (1988). DNA probes for Shiga-like toxins I and II and for toxinconverting bacteriophages. Journal of Clinical Microbiology 26, 1292-1297.

O'Brien, A. D., Lively, T. A., Chen, M. E., Rothman, S. W. \& Formal, S. B. (1983). Escherichia coli $0157 . H 7$ strains associated with haemorrhagic colitis in the United States produce a Shigella dysenteriae 1 (Shiga)-like cytotoxin. Lancet i, 702.

O'Brien, A. D., Newland, J. W., Miller, S. F., Holmes, R. K., SMith, H. Williams \& Formal, S. B. (1984). Shiga-like toxin-converting phages from Escherichia coli strains that cause hemorrhagic colitis or infantile diarrhea. Science 226, 694-696.
Pugsley, A. P. (1985). Escherichia coli K12 strains for use in the identification and characterization of colicins. Journal of General Microbiology 131, 369376.

Rietra, P. J. G. M., SMith, H. R., Willshaw, G. A., Field, A. M., Scotland, S. M. \& Rowe, B. (1989). Comparison of Vero cytotoxin (VT)-encoding phages from Escherichia coli. In Proceedings of the First International Symposium and Workshop on Verocytotoxin-producing Escherichia coli Infection (in the Press).

Scotland, S. M., Day, N. P. \& Rowe, B. (1980). Production of a cytotoxin affecting Vero cells by strains of Escherichia coli belonging to traditional enteropathogenic serogroups. FEMS Microbiology Letters 7, 15-17.

Scotland, S. M., Smith, H. R., Willshaw, G. A. \& RowE, B. (1983). Vero cytotoxin production in strain of Escherichia coli is determined by genes carried on bacteriophage. Lancet ii, 216.

Scotland, S. M., Smith, H. R. \& Rowe, B. (1985). Two distinct toxins active on Vero cells from Escherichia coli O157. Lancet ii, 885-886.

Scotland, S. M., Smith, H. R., Willshaw, G. A. \& Rowe, B. (1987). Properties of strains of Escherichia coli belonging to serogroup 0157 with special reference to production of Vero cytotoxins VTI and VT2. Epidemiology and Infection 99, 613-625.

Scotland, S. M., Rowe, B., Smith, H. R., Willshaw, G. A. \& Gross, R. J. (1988). Vero cytotoxinproducing strains of Escherichia coli from children with haemolytic uraemic syndrome and their detection by specific DNA probes. Journal of Medical Microbiology 25, 237-243.

Sherwood, D., SNodgrass, D. R. \& O'Brien, A. D. (1985). Shiga-like toxin production from Escherichia coli associated with calf diarrhoea. Veterinary Record 116, 217-218.

Smith, H. R., Day, N. P., Scotland, S. M., Gross, R. J. \& RowE, B. (1984). Phage-determined production of Vero cytotoxin in strains of Escherichia coli serogroup 0157. Lancet i, 1242-1243.

Smith, H. R., Scotland, S. M., Willshaw, G. A., Wray, C., McLaren, I. M., Cheasty, T. \& Rowe, B. (1988). Vero cytotoxin production and presence of 
VT genes in Escherichia coli strains of animal origin. Journal of General Microbiology 134, 829-834.

SMITH, H. Williams, Green, P. \& Parsell, Z. (1983). Vero cell toxins in Escherichia coli and related bacteria: transfer by phage and conjugation and toxic action in laboratory animals, chickens and pigs. Journal of General Microbiology 129, 3121-3137. Strockbine, N., Marques, L. R. M., Newland, J. W., Smith, H. Williams, Holmes, R. K. \& O'BRIEN, A. D. (1986). Two toxin-converting phages from Escherichia coli 0157:H7 strain 933 encode antigenically distinct toxins with similar biologic activities. Infection and Immunity 53, 135-140.

Weinstein, D. L., Jackson, M. P., SAmuel, J. E., Holmes, R. K. \& O'Brien, A. D. (1988). Cloning and sequencing of a Shiga-like toxin type II variant from an Escherichia coli strain responsible for edema disease of swine. Journal of Bacteriology 170, 42234230.

Willshaw, G. A., Smith, H. R., Scotland, S. M. \& Rowe, B. (1985). Cloning of genes determining the production of Vero cytotoxin by Escherichia coli. Journal of General Microbiology 131, 3047-3053.

Willshaw, G. A., Smith, H. R., Scotland, S. M., FieLD, A. M. \& RowE, B. (1987). Heterogeneity of Escherichia coli phages encoding Vero cytotoxins: comparison of cloned sequences determining VT1 and VT2 and development of specific gene probes. Journal of General Microbiology 133, 1309-1317. 